\title{
The Sense of Smell in Logopaedic Theory and Practice
}

\section{Zmysł węchu w teorii i praktyce logopedycznej}

\author{
Keywords: smell, olfactory disorders, diagnosis and speech therapy of sensory disorders (smell) \\ Słowa kluczowe: węch, zaburzenia węchu, diagnoza i terapia logopedyczna zaburzeń węchu
}

\begin{abstract}
Olfactory disorders concern many diseases of laryngological, neurological, oncological and gerontological origins, and sometimes are one of the diagnostic symptoms of a serious illness. The aim of this article is to describe the sense of smell (anatomy, physiology, functions, etiology and characteristics of disorders) and, in particular, to present this sense in the context of logopedic theory and practice. Speech therapists may inter alia assess the functioning of the sense of smell on the basis of an interview with the patient or caregiver, make a general evaluation of the functioning of the sense of smell, using different olfactory samples. As part of speech therapy, speech therapists may include stimulation of the sense of smell through various exercises, e.g. odour differentiation exercises, exercises in guessing and naming different odours, exercises in differentiating odour intensity, exercises in searching the source of smell.
\end{abstract}

\section{Streszczenie}

Zaburzenia węchu dotyczą wielu chorób o różnym podłożu: laryngologicznym, neurologicznym, onkologicznym, gerontologicznym, a niekiedy są jednym z objawów diagnostycznych poważnej choroby. Celem artykułu jest opisanie zmysłu węchu (anatomii, fizjologii, funkcji, etiologii i charakterystyki zaburzeń), a przede wszystkim zaprezentowanie tego zmysłu

\footnotetext{
* Uniwersytet Łódzki, Wydział Filologiczny, Instytut Filologii Polskiej i Logopedii, Zakład Dialektologii Polskiej i Logopedii, ul. Pomorska 171/173, 90-236 Łódź, e-mail: renata.marciniak@uni.lodz.pl, ORCID: https://orcid.org/0000-0001-6301-8820.
} 
w kontekście teorii i praktyki logopedycznej. Logopeda może m.in. na podstawie wywiadu z pacjentem lub opiekunem pacjenta oraz za pomocą różnych próbek zapachowych dokonać oceny funkcjonowania zmysłu powonienia. W ramach terapii logopedycznej może natomiast prowadzić stymulację zmysłu węchu poprzez różne ćwiczenia, np. różnicowania zapachów i ich intensywności, odgadywania i nazywania różnych zapachów, poszukiwania źródła zapachów itp.

\section{Introduction}

For several years now, speech therapy has been discussed in the context of the socalled holistic approach to the patient regarding both the diagnosis and the therapeutic process.

The holistic approach to the human being involves understanding the close relationship between the development and functioning of individual cognitive spheres. People learn the world and understanding reality through the senses. The human brain analyses tactile, auditory, gustatory, visual and olfactory stimuli (or those less familiar) things which are felt both inside and outside the body [Biel, 2015, p. 12].

In the process of exploring the world, it is very important to integrate the sensations which flow to the brain through all sensory paths to create a multisensory image. In this way, linguistically definable concepts can be developed in the mind. As Korendo argues, "This precise process is compromised when at least one of the senses becomes dysfunctional. The loss of one dimension translates into a cognitive deficit which then directly affects the language constructed in the mind" [Korendo, 2017, p. 109] and "the multisensory cognition of the world and integration of information flowing along different routes is a prerequisite for proper cognitive and linguistic development" [Korendo, 2017, p. 110].

While the senses of hearing and sight have been the subject of many works so far [cf. e.g.: Gunia, 2006; Paplińska, 2010; Gałkowski, Radziszewska-Konopka, 2011; Kurkowski, 2013; Paczkowska, Szmalec, 2014; Skibska, 2014; Kucharczyk, 2015; Muzyka-Furtak, 2015; Belzyt, 2016; Kurkowski, 2016; Wróblewska, 2019], the sense of smell is often referred to as one of the least appreciated human senses, and its disorders tend to be underestimated [Dżaman et al., 2007, p. 832].

Increased interest in the sense of smell and the appreciation of its role has been observed twice in the 21st century. The 2004 Nobel Prize in Medicine was awarded to Linda B. Buck and Richard Axel for their research into the mechanisms of olfactory perception and the discovery of olfactory receptor genes. Using modern molecular biology methods, Buck and Axel explained the molecular and cellular mechanisms of olfactory molecules detection by the olfactory system. They described a multigene

1 Unless indicated otherwise, quotations in English were translated from Polish. 
family of genes encoding odorant receptors which are $\mathrm{G}$ protein-coupled receptors (the so-called GPCRs) [Potargowicz, 2008, p. 88]. Their discovery was groundbreaking, as it explained odor-sensing at the molecular level and triggered new directions of research on the genetic determinants of smell and the functioning of the olfactory system, from receptors to higher brain centres [Białaczewski, 2005, p. 165].

The Covid-19 (SARS-CoV-2) pandemic is the second occasion on which interest in the smell and appreciation of its role can be observed. The loss of taste or smell is one of the symptoms of Covid-19 infection, beside among others, fever, dry cough, fatigue, muscle pain, diarrhea, breathing difficulties or shortness of breath. Reports of scientists published in journals such as "European Archives of Oto-Rhino-Laryngology" and "Journal Investigational Allergology and Clinical Immunology" indicate that women prevailed among the respondents with olfactory and taste disorders (63.5\%), and changes in smell and taste were experienced by $53-70 \%$ and $52-65 \%$ of all patients respectively. It was also pointed out that the loss of smell and taste was most frequently observed in the group of patients with Covid-19 aged 42-46. Most often these symptoms precede the feeling of dyspnea and cough, but it is also not uncommon that they are the only, isolated symptoms of the coronavirus in the initial phase. Smell and taste disorders accompany people for many weeks after the other symptoms of infection have disappeared. The reverse has also been reported, albeit less frequently, when patients infected with Covid-19 experienced an overly sensitive sense of smell and taste [Altin et al., 2020; Boscolo-Rizzo et al., 2020; IzquierdoDomínguez et al., 2020a; Izquierdo-Domínguez et al., 2020b; Lechien et al., 2020].

As it appears, olfactory disorders concern many diseases of laryngological, neurological, oncological and gerontological origins. The aim of this article is to describe the sense of smell (anatomy, physiology, functions, etiology and characteristics of disorders) and, in particular, to present this sense in the context of logopedic theory and practice.

\section{Anatomy, physiology and functions of the sense of smell}

Our nervous system allows us to follow a multistage processing of olfactory stimuli to differentiate several thousand different odors.

The olfactory region reached by airborne olfactory molecules made of olfactory epithelium and having a total surface area of approximately $5 \mathrm{~cm}^{2}$, is located in the vault of the nasal cavity, in the upper nasal passages of both nasal cavities. A large number of olfactory receptors located in the olfactory epithelium of the nasal cavity enables the detection of a given smell. The olfactory epithelium consists of bipolar cells (no comma needed) supporting cells and basal cells. On the one hand, the bipolar cells perform a receptor function and, on the other, they are the first neuron of the olfactory tract. Each bipolar cell has from 8 to 20 eyelash towards the lumen of the nasal cavity and 
immersed in the mucus. This is the only place in the human body where the sensory cells come into direct contact with the external environment. The concentration of hydrophobic increases when aromatic molecules in the watery mucus layer are dissolved (which increases their concentration). This is the first mechanism of olfactory signal amplification. The mucus produced by the supporting cells contains, among other things, odorant binding proteins (OBP). These are proteins responsible for the transport of odorant substances, making them available to receptors localized on the cilia. The odorant substance is received in the olfactory cilia, and this is where the sensory transduction (transmission) begins. The second end of bipolar cells are axonal extensions, running through the perforations in the cribriform plate and forming olfactory nerves. Axons of bipolar cells end in synapses in the olfactory bulb on dendrites of mitral cells, which form the olfactory glomeruli. Mitral cells, located in the olfactory bulb, are the second neuron of the olfactory tract and they send the axons through the olfactory tract to the area of the olfactory trigone and the anterior perforated substance. The third neuron of the olfactory tract can be found in the structures of the rhinencephalon, including the hippocampal gyrus, piriform gyrus, olfactory knob, anterior olfactory nucleus and amygdala. The amygdala and hippocampus are responsible for the central processing of olfactory information. Impulses running from the olfactory epithelium are inhibited at the level of the olfactory bulb. The olfactory glomeruli or, more precisely, neurons inhibiting mitral cells, are also reached by the efferent axons from the anterior olfactory bulb and the septum [Sienkiewicz-Jarosz, 2012, p. 7; cf. also Jabłońska-Trypuć, Fabiszewski, 2006].

Signals from the olfactory cells arrive to the rhinencephalon (medial cortex of the hemisphere surface), hippocampal gyrus and amygdala, which are located deep inside the temporal lobe. Some nerve impulses from the olfactory receptors run to the cortex of the brain, where conscious olfactory perception takes place, while some end in the limbic system, which is why smells are associated with emotional reactions [Potargowicz, 2008, p. 90].

The following functions of the olfactory organ in humans are listed in the literature [Rapiejko, 2006, pp. 5-6; Janczewski, 2007, p. 225; Potargowicz, 2008, p. 88]:

- creating a feeling of complete mental comfort, having an impact on the quality of life by sensing and evaluating the smells of the natural world around us;

- selecting suitable foods (their quality and freshness) and maintaining physiological appetite on an appropriate level, participating in the process of secreting saliva and gastric juice under the influence of pleasant odours, warning against spoiled foods that give off unpleasant smells;

- contributing greatly to the perception of taste sensations: loss of the sense of smell is accompanied by the loss of the ability to experience tastefully;

- warning of hazardous substances in the environment which pose a threat to life and health (smoke, toxic gases), locating the source of a dangerous or unpleasant smell; 
- providing a source of aesthetic experiences and feelings, emotional (joy, sadness, etc.) and sexual behaviour;

- facilitating self-control and control of hygienic condition (smell of sweat and excretions);

- obtaining important social information (recognition of one's mother, child, a role in initiating the sucking reflex);

- experiencing olfactory disorders can be a symptom of serious damage to the nervous system;

- having an efficient olfactory organ is necessary for the performance of certain professions (sommeliers, chefs, pharmacists, firefighters, chemical laboratory workers);

- smells stimulate greater mental effort.

The sense of smell has two functions [Rapiejko, 2006, p. 6]:

- basic functions (detecting odours in the ambient, sniffing, determining the intensity of the substance that is a source of odour and evaluating it) and,

- higher functions (learning to distinguish between odours and identifying them, memorising and integrating different smells).

Research has shown that neurogenesis processes in one's individual life takes place in the structure responsible for the sense of smell, i.e. the olfactory bulb, which is also proof that olfactory function is important in the life of people. The phenomenon of olfactory memory cannot be overlooked either. Furthermore, of the many cells that produce neurotrophic agents, it is olfactory glial cells, being the most efficient, that have become a hope in the treatment of spinal cord injuries [Potargowicz, 2008, p. 88].

\section{Olfactory disorders: etiology and classification}

Halina Sienkiewicz-Jarosz [2012, p. 7] lists three types of causes of olfactory disorders:

- conduction causes,

- sensorineural causes and,

- causes related to the central nervous system.

Conduction disorders are associated with impaired contact of odorous substances with the sensory epithelium, usually due to nasal passage disorders (malformations, post-traumatic lesions, polyps, deviated septum, hypertrophy of nasal conchae, allergic rhinosinusitis, chronic paranasal sinusitis, allergic lesions, nasal and nasopharyngeal tumours) [Sienkiewicz-Jarosz, 2012, pp. 7-8; cf. also Rapiejko, 2006, p. 8].

Sensorineural disorders are usually caused by damage to the olfactory epithelium. They can be caused by chronic atrophic rhinitis, toxic damage (medicines, tobacco smoke, inorganic dusts) or cocaine use. Damage to olfactory neurons, especially disruption of olfactory nerves, or damage to olfactory bulbs tend to be caused by cranial 
trauma, particularly fractures of the base of the anterior cranial fossa. Another cause can be tumours of the frontal lobe or the olfactory groove [Sienkiewicz-Jarosz, 2012, p. 8]. Other causes enumerated by Piotr Rapiejko include acute viral infections, iatrogenic trauma, hormonal disorders, taking medication with toxic effects on the olfactory nerves or disorders associated with old age (presbyosmia) [Rapiejko, 2006, p. 8].

Central olfactory disorders may be caused by vascular, demyelinating lesions in multiple sclerosis and brain tumours [Sienkiewicz-Jarosz, 2012, p. 8].

Normal olfactory function is referred to as normosmia as opposed to olfactory disorders generally knowns as dysnosmia. In quantitative terms, olfactory disorders can be divided into: a) hyposmia (microsmia), i.e. weakening or impairment of smell; b) anosmia - a total loss of the ability to smell; c) hyperosmia, or excessive sensitivity to olfactory stimuli, an increased olfactory acuity, olfactory hypersensitivity. Olfactory disturbances may be one-sided (e.g. unilateral anosmia) or total (e.g. bilateral anosmia) [Sienkiewicz-Jarosz, 2012, p. 7].

In qualitative terms, olfactory disorders include: a) parosmia, or the perception of false odours; b) pseudosmia, i.e. a sensation of odour without the appropriate stimulus (olfactory illusions); c) phantosmia, or olfactory hallucinations; d) cacosmia, or an unpleasant smell illusion. The loss of ability to recognise familiar smells is called anosmia [Sienkiewicz-Jarosz, 2012, p. 7].

Ewa Czerniawska [2012, pp. 102-103], in turn, enumerates the following olfactory dysfunctions:

- anosmia - an olfactory disorder consisting in a total loss of the ability to smell;

- partial (selective) anosmia - a disorder consisting in a loss of the ability to smell certain smells;

- hyposmia (also referred to as microsmia) - reduced ability to detect odours;

- hyperosmia - a heightened sense of smell;

- dysosmia (cacosmia, parosmia and troposmia) - distortion or alteration of the perception of smell;

- phantosmia (also known as olfactory hallucinations) - experiencing olfactory sensations in the absence of olfactory stimuli;

- olfactory agnosia - a situation in which a patient, often after a stroke, is not aware of the olfactory stimulus, although the processing of the smell, the language and cognitive functions are not impaired; and,

- presbyosmia - olfactory disorders of unknown etiology in the elderly.

The International Statistical Classification of Diseases and Related Health Problems (ICD-10) classifies olfactory disorders under the following codes:

- R43 - Disturbances of smell and taste;

- R43.0 - Anosmia;

- R43.1 - Parosmia;

- R43.8 - Other and unspecified disturbances of smell and taste; and the code G52.0 is used to specify disorders of olfactory nerve. 


\section{Diagnosis of olfactory disorders and examination of the sense of smell}

The examination of the sense of smell should be an integral part of clinical examination, and patients' complaints concerning olfactory disorders require careful analysis [Sienkiewicz-Jarosz, 2012, p. 10].

In the case of signals from the patient concerning olfactory disorders, it is necessary to conduct an interview which should, according to Sienkiewicz-Jarosz [2012, p. 9], include questions about:

- onset of symptoms (sudden, insidious);

- functioning of the sense of smell before the onset of the disorder (normal, impaired);

- co-occurrence of taste disorders;

- a preceding factor (trauma, infection, other);

- severity of the disturbance (perceived odours, reaction to irritants);

- pattern of disorders (constant or paroxysmal, non-selective or selective, concerning certain odours);

- coexisting diseases: neurological illnesses, allergies, sinusitis, Sjögren syndrome, Paget's disease, Wegener's granulomatosis, endocrine diseases (Addison's disease, hypopituitarism, Cushing's syndrome), mental illness (schizophrenia);

- the medicines used (sestines, chemotherapy, antacids which may impair the absorption of vitamins);

- operations (olfactory disorders can be both a symptom of frontal lobe tumours and a complication resulting of their surgical treatment, sometimes they are a complication of the surgical treatment of the deviated nasal septum);

- smoking tobacco (toxic damage), consumption of alcohol (diet, vitamin deficiency);

- employment (environmental factors);

- other co-existing symptoms (disorders of the visual field, edema or atrophy of the optic disc, central scotoma); and

- family medical history (genetically determined diseases).

An consultation is recommended in specific cases using an endoscopic examination of the nose when suspecting polyps, chronic inflammatory conditions, etc. and a neurological consultation when suspecting neuropathy, degenerative diseases and epilepsy [Sienkiewicz-Jarosz, 2012, pp. 9-10].

Brain magnetic resonance imaging it the neuroimaging examination that provides the most information on the possible causes of olfactory disorders, although computed tomography is still the most commonly performed examination in the case of paranasal sinusitis [Sienkiewicz-Jarosz, 2012, p. 10].

Currently available methods allow the assessment of many different aspects of olfactory function through specific olfactory tests: a) odour detection threshold 
(identifying the lowest recognised concentration of the test substance); b) odour identification threshold (the lowest concentration allowing recognition of odours), c) discrimination threshold (concentrations at which it is possible to differentiate between two substances), and, d) identification of suprathreshold stimuli (the subject usually selects one of four responses after being exposed to a given odour). One may also evaluate intensity and pleasantness through a subjective evaluation of the suprathreshold stimuli. All these tests are referred to as subjective because during the examination the patient is confronted with a smell and asked to either signal the presence of a stimulus or to select an identified odour from a list of responses [Sienkiewicz-Jarosz, 2012, p. 8].

The olfactory test can be subdivided into an odour identification test and odour perception threshold test using company tests with different odours.

The Elsberg-Levy blast-injection method as modified by Pruszewicz is the most commonly used olfactory test. It allows to measure the odour sensation threshold as well as odour identification threshold. This olfactory test consists of injecting a stream of odorous air of a strictly defined volume into the nasal cavity. The odour sensation threshold testis conducted using the blast-injection method with a special instrument called olfactometre. The test is usually performed using oils, such as lemon, mint, vanilla and freshly ground coffee [Jadczak, Rapiejko, Jurkiewicz, 2005, p. 190].

In recent years, scientists have succeeded in registering olfactory evoked potentials (OEPs). It is an innovative method of objective examination of the sense of smell registering changes in brain bioelectrical activity after stimulating the receptors in the olfactory area of the nasal cavity. A repeatable application of olfactory stimuli was obtained with the use of a modified Elsberg blast-injection method. Two responses to stimuli irritating nerve $\mathrm{V}$ endings and nerve I endings were differentiated after analysis of latency times of evoked olfactory cortical potentials [Obrębowski, Świdziński, Świdziński, 2004, pp. 253-258; Repetowski et al., 2010, pp. 87-88].

In addition to the classic olfactory test, which consists of giving the patient a sniff of coffee, vanilla and an irritating solution of ammonia (to assess the sensitivity of nerve V), the currently used subjective tests include [Sienkiewicz-Jarosz, 2012, p. 9]:

- The University of Pennsylvania Smell Identification Test (UPSIT) is a test which is easy to perform in a clinic environment as well as at home. It consists of booklets containing 10 items, each in the form of microcapsules applied on paper ( 40 items in total). The test is interpreted based on the number of correct answers.

- Cross-Cultural Smell Identification Test (CC-SIT) is a test analogous to the UPSIT test, but contains only 12 items selected from UPSIT.

- Connecticut Chemosensory Clinical Research Center Test (CCCRC test) is used to assess both the ability to detect and discriminate between odours. The test contains substances that stimulate the olfactory nerve and the trigeminal nerve. 
- The Sniffin' Sticks test - applied for olfactory threshold testing, discrimination and identification of odour, using sticks impregnated with different odours. The test result is the sum of correctly identified fragrances.

Objective olfactory examination is possible thanks to [Sienkiewicz-Jarosz, 2012, p. 9]:

- olfactory event-related potentials (OERP); they are a response to intranasal chemical stimulation; in the case of OERP, it is possible to distinguish between anosmia, normosmia and hyposmia;

- the electroolfactogram (EOG), or potentials recorded at the surface of the olfactory epithelium in response to its stimulation by aromatic substances; this test can, for example, assess whether the olfactory impairment is sensorineural. It is also worth mentioning the felt-tip pen test by Piotr Rapiejko [2016]. The test, which is of an indicative nature, consists in applying an odorous substance to a sheet of paper using a felt-tip pen. The person tested is asked to name the odour after putting a piece of paper to their nose. Different smells can be used in the test, including vanilla, lemon, mint, rose fragrance, nitro paint solvent, ammonia, natural gas odorant.

Nowadays, imaging techniques are also used in olfactory research. Thanks to magnetic resonance imaging, it is possible to examine olfactory bulbs, whereas in functional magnetic resonance imaging and positron emission tomography (PET) it is possible to assess activation of brain structures in response to olfactory stimuli [Sienkiewicz-Jarosz, 2012, p. 9].

\section{The sense of smell in ENT and speech therapy: theory and practice}

The sense of smell is sensitive to numerous physiological and pathological changes in the body, and olfactory disorders may be a characteristic symptom of nasal polyps, rhinitis or chronic paranasal sinusitis.

Medical literature rarely draws attention to the fact that the increasing impairment of smell (but also of taste) ${ }^{2}$ may be a measure and the first alarming symptom perceived by the patient, informing about the "regrowth" of polypoid lesions in the nasal cavity [Dżaman et al., 2007, p. 831]. However, due to the anatomical proximity of the structures responsible for the conduction of olfactory stimuli (also taste) to the area of polyp formation, it can be assumed that the appearance of pathological

\footnotetext{
2 The mutual relationship between the sense of taste and smell is described in the literature as "clinical unity" [Pruszewicz, Durska-Zakrzewska, Rydzewski, 1984]. The phenomenon of the impact of an olfactory dysfunction on the impairment of taste sensations is explained by the similarity of these two senses both in terms of the type of stimulus and the shape of nerve cells in both senses [Dizaman et al., 2007, p. 832].
} 
polypoid lesions in this area will significantly affect the functioning of the sense organs [Dżaman et al., 2007, p. 831].

Sensory impairment in patients with nasal polyps may have a complex aetiology, combining elements of sensory and nervous disorders as well as conduction disorders. Polyps directly affect the olfactory receptor area and have an indirect impact on the mucous membrane of the mouth and tongue, where the taste buds are located. Thus, the mass of the polyp can impair the sense of smell by blocking the olfactory air from reaching the olfactory field and contribute to disorders of the oral mucosa, which becomes dry through continuous mouth breathing. This, in turn, results in an abnormal perception of taste [Dżaman et al., 2007, p. 836]. Impaired patency of the nasal cavity is also often the result of trauma caused by rhinosurgical procedures and the consequent tendency to form adhesions and cicatrisation in the vicinity of the mucous membrane of the olfactory field. It is estimated that iatrogenic lesions cause olfactory disorders in approximately $2-3 \%$ of operated cases [Dżaman et al., 2007, p. 832].

Finally, the disorders of smell (and also of taste) in patients with nasal polyps are sometimes a side effect of the implemented therapy and the ensuing damage to the nasal mucosa following the excessive use of a mucosal decongestant [Dżaman et al., 2007, p. 836].

The research shows that olfactory disorders occurred in more than half of patients with nasal polyps and the degree of olfactory disorders correlated with the size of polyps lesions [Dżaman et al., 2007, p. 836].

Loss of smell is also observed in rhinitis. It may occur temporarily during a period of acute viral, bacterial and allergic inflammation. Loss of smell which is chronic and occurs with low intensity may be caused by nasal polyps and oedema. Severe total anosmia is a consequence of trauma. It can also be caused by damage to nerve endings after a flu infection. Sometimes topical glucocorticosteroid therapy is also responsible for olfactory disorders. Loss of the sense of smell caused by damage to the olfactory cells does not prevent the patient from feeling the smell of ammonia and petrol, compounds that are perceived thanks to the sensory activity of the trigeminal nerve [Samoliński, 2007, p. 284].

Finally, olfactory disorders or loss of the sense of smell represent one of the symptoms of paranasal sinusitis, i.e. acute paranasal sinusitis, chronic paranasal sinusitis without polyps and chronic paranasal sinusitis with polyps. The disorder or loss of the sense of smell may be accompanied by: impaired nasal patency/blocked nasal cavities, rhinitis (anterior/posterior), pain/distension of the facial skeleton [Tomaszewska, Krzeski, 2018, p. 76]. Disorders of the sense of smell (usually of the conduction type) develop gradually, particularly in patients with polyp formation and airflow obstruction in nasal cavities [Krzeski, 2007, p. 312; Resler, 2019].

Organic rhinolalia clausa is caused by disease lesions in the entire nasal emission canal, from the anterior nostrils to the nasal part of the pharynx, leading to the 
abolition or significant impairment of nasal patency [Sekula, Pruszewicz, 2019, p. 232].

The rhinolalia clausa (denasalisation, hyponasality, rhinophonia and hyporhinophonia) occurs when nasal resonance is reduced, especially in the case of nasal sounds, as a result of pathological changes. In addition to nasal consonants, nasal vowels are also altered as a result of suppression of certain component tones in the nasal cavity and nasal pharynx [Sekula, Pruszewicz, 2019, p. 232]. Due to obstruction of the nasal tract, no nasal resonance is produced during articulation of nasal sounds. Nasal sounds resemble oral sounds with a similar articulatory system: $m$ sounds like $b, n$ resembles $d, Q$ is similar $o$, $e$ bears a resemblance to $e$ [Styczek, 1979, p. 371; Sekula, Pruszewicz, 2019, p. 233].

Choanal polyps are (rarely) the cause of so-called posterior rhinolalia clausa. In acute or chronic rhinitis, the oedema of the mucous membrane causes rhinolalia clausa [Sekula, Pruszewicz, 2019, p. 233].

In the initial assessment of nasalisation, i.e. Czermak mirror test, no evaporation of a mirror applied to anterior nostrils is observed during the articulation of nasal sounds. The Seeman and Gutzmann tests are also negative [Sekula, Pruszewicz, 2019, p. 233].

A speech therapist diagnosing rhinolalia clausa in the patient with olfactory disorders should refer them further for laryngological tests. The organic treatment of conditioned rhinolalia clausa is essentially only surgical [Sekula, Pruszewicz, 2019, p. 233]. The procedure in the case of rhinolalia clausa involves, as it was indicated, removing its cause and then, if necessary, teaching nasal sounds. Speech therapy should include physiological breathing exercises, activities teaching to differentiate inhalation and exhalation, exercises showing how to activate the nasal resonator using the strategies of feeling nasal bone vibrations as well as strategies of differentiating nasal and oral speech sounds (Encyklopedia logopedii, n.d.).

Irena Styczek suggests starting speech therapy exercises with free inhalations through the nose with the mouth closed. The nasal consonant $[\mathrm{m}]$ should be pronounced by feeling the vibration of the nasal wings and a mirror placed against the nostrils. In syllables such as $m a, m o, m u, m e, m y$, the consonant $[m]$ should be pronounced in a protracted manner. Attention should be paid to ensure that vowels adjacent to the $m$ sound are not nasalised. After practising the $[m]$ sound in words, other sounds should be rehearsed in the same way [Styczek, 1979, p. 373].

When children have nasal polyps, one should not fail to mention how these abnormal anatomical conditions make it difficult or impossible for a child to breathe freely, or physiologically (or through the nose). Due to the lack of nasal patency, the way of breathing changes (inhalation and exhalation occur through the mouth). This has a negative effect on the tone of facial muscles, swallowing and the position of the tongue. Incorrect breathing leads to speech defects (e.g. interdental lisp) or speech disorders (e.g. delayed speech development). The reduced muscle tone resulting from the 
permanently open mouth causes the tongue to lie flat on the floor of the mouth and assume an incorrect resting position. This creates a risk of: a) extending the tongue out of the oral cavity, b) formation of malocclusions (e.g. apertognathia), c) occurrence of upper respiratory tract infections, $d$ ) enlargement of the adenoids and the palatine tonsils, e) hearing impairment, f) unclear, unintelligible speech, or even delayed speech. It is therefore advisable to diagnose the cause of the abnormal breathing as soon as possible and to implement effective treatment and speech therapy.

\section{The sense of smell in oncological theory and practice}

Olfactory disorders can be a symptom - sometimes the only symptom - of tumours located in the nasal cavity and brain tumours [Sienkiewicz-Jarosz, 2012, p. 10]. The sense of smell is also severely impaired after total laryngectomy. The olfactory organ is not damaged during the surgery, yet the change in the airflow path while breathing through a tracheostomy makes it difficult for olfactory particles to reach the olfactory region of the nasal cavity with the air [Zimmer-Nowicka et al., 2008, p. 134]. The dysfunction is caused by two reasons: the inability of odorous substances to penetrate the olfactory epithelial region and atrophic changes of this epithelium [Okła, 2007, p. 6]. Most people after laryngectomy experience significant smell impairment in the form of parosmia and hyposomia [Okła, 2007, p. 6; Zimmer-Nowicka et al., 2008, pp. 134, 137]. Olfactory disorders directly reduce the sense of taste as well [Okła, 2007, p. 6].

One of the elements of rehabilitation of patients after laryngectomy should therefore consist in the rehabilitation of the olfactory organ, i.e. exercises aimed at improving the airflow in the nasal cavity [Zimmer-Nowicka et al., 2008, p. 134].

Joanna Zimmer-Nowicka and co-authors propose the following exercises conducted under the supervision of speech therapists:

- making chewing movements with the mouth closed;

- making yawning movements with the mouth closed;

- breathing in the air with the wing of the nose pressed by moving the soft palate through the nose, then releasing the pressure.

These exercises should be performed for both right and left side [Zimmer-Nowicka et al., 2008, p. 135].

In her monograph titled Mowa przełykowa. Studium onkologopedyczne, Agnieszka Hamerlińska stresses that:

\footnotetext{
[...] the technique of yawning with closed lips, also known as polite yawning, is particularly useful in olfactory therapy of patients with removed larynx. This technique involves sticking the tongue to the palate and lowering the jaw while keeping the mouth open. It induces a negative pressure in the oral cavity, which generates an airflow through the nose, enabling odorous substances to reach the olfactory epithelium again [Hamerlińska, 2019b, p. 132].
} 
The fact that rehabilitation of the olfactory organ in post-laryngectomy patients is effective is evidenced by the results of research conducted in several countries, including the Netherlands, Sweden and the United States [cf. Zimmer-Nowicka et al., 2008, pp. 136-137].

In Poland, researchers from the Head and Neck Cancer Clinic of the Medical University of Lodz evaluated the efficiency of the olfactory organ in patients after laryngectomy and analysed the course and effectiveness of olfactory rehabilitation conducted as part of routine postoperative care in these subjects [Zimmer-Nowicka et al., 2008, p. 134]. Out of 80 patients in the study group, as many as 35 patients (43.8\%) observed an improvement in the sense of smell after rehabilitation. Lack of improvement after the rehabilitation was reported by 45 patients (56.2\%). The research indicates that improvement in the ability to smell after rehabilitation was significantly more frequent in the group of patients who did not undergo radiotherapy. In addition, it was observed that in the group with improvement in the ability to smell (successful rehabilitation), the time after surgery was $3.9 \pm 4.3$ years on average, whereas the time after the treatment in the group without improvement was longer and amounted to $5.0 \pm 4.2$ years [Zimmer-Nowicka et al., 2008, p. 135].

Agnieszka Hamerlińska [2019c, p. 199] also confirms the effectiveness of smell training in speech therapy of oncological patients on the basis of the research conducted in a group of 19 patients in 2018.The results of her research are confirmed by the achievements of scientists from Łódź [Hamerlińska, 2019a, p. 144].

\section{The sense of smell in neurologopaedic theory and practice}

As Ewa Czerniawska points out, problems with sensing or recognising smells may indicate the development of serious diseases of the central nervous system [Czerniawska, 2012, p. 104]. Neurodegenerative diseases in which the sense of smell is affected include neuronal disorders, i.e. disorders caused by damage to receptor cells and olfactory tracts [Czerniawska, 2012, p. 103].

Olfactory dysfunctions are present in disease entities such as ${ }^{3}$ [Czerniewska, 2012, pp. 103-104]:

- brain tumours;

- brain injuries;

- schizophrenia;

- Down syndrome;

- Huntington's disease;

- multiple sclerosis;

3 Neurodegenerative diseases, such as Parkinson's disease or Alzheimer's disease, in which olfactory disorders are one of the first symptoms, sometimes years before the onset of motor or memory disorders [Sienkiewicz-Jarosz, 2012, 10] are discussed in the subsection on gerontologopaedics. 
- amyotrophic lateral sclerosis; and,

- frontal lobe gliomas.

In genetically determined diseases, such as Huntington's disease, olfactory impairment is probably due to a neurodegenerative process [Sienkiewicz-Jarosz, 2012, p. 8].

An interesting and unique property of the sense of smell is that, on one hand, olfactory neurons degenerate quite rapidly (after one to two months), but on the other, they have a rare feature of nerve cells, i.e. a strong ability to regenerate (neurogenesis) [Czerniawska, 2012, p. 92].

Rehabilitation of olfactory disorders is therefore important and can be integrated into the therapy by a (neuro)speech therapist. The specialist can use substances to stimulate either the olfactory nerve or the olfactory nerve and the trigeminal nerve or the glossopharyngeal nerve [Janczewski, 2007, pp. 228-229]:

- substances which mainly stimulate the olfactory nerve; these include numerous spices, non-alcoholic perfume, coffee and tea;

- substances that stimulate the olfactory nerve and the final branches of the trigeminal nerve in the nasal mucosa, including essential substances with odours conventionally described as pungent, such as camphor, ammonia, ether and all acids (acetic acid) and alcoholic solutions;

- substances that stimulate the olfactory nerve and the final branches of the glossopharyngeal nerve on the tongue base: chloroform (sweetness) and pyridine (bitterness).

When using olfactory therapy it is helpful to keep in mind as cited by Ewa Czerniawska, that pleasant odours are processed by the left hemisphere and unpleasant ones - by the right hemisphere [Czerniawska, 2012, p. 93]. Using scents adapted to the patient, the speech therapist can conduct exercises to stimulate the sense of smell, exercises to differentiate between scents, to distinguish between their intensities, to guess and name the scents, etc.

Agnieszka Kwiatkowska, in turn, proposes a multisensory therapy in patients in a minimally conscious state and locked-in syndrome, including stimulation of the sense of smell. Based on the Morning Circle method, the author has developed her own multisensory therapy programme, using natural phenomena typical of the four seasons [Kwiatkowska, 2014, pp. 97-100].

Disorders and olfactory concerning the sense of smell are not only relevant for adults. There are also olfactory dysfunctions in children.

Writing about the sense of smell in neurology, one cannot forget about dysfunctions in the modulation of sensory input which are manifested, among others, by sensory defensiveness or aversive reactions to several sensory modalities, i.e. touch, sound, movement and also odour [Przyrowski, 2002, p. 207].

As Zbigniew Przyrowski points out, Jean Ayres draws attention to the following dysfunctions in recording sensory stimuli, including olfactory stimuli, in describing two types of sensory integration dysfunctions in autistic children [Przyrowski, 
2002, p. 209]. Therefore, in Przyrowski's opinion, it seems important to disseminate knowledge about sensory integration processes, as it may contribute to the early recognition of disorders of these processes.

In the prepared Sensorimotor Questionnaire, Przyrowski stresses the following aspects connected with the sense of smell in a child who [Przyrowski, 2012; 2019]:

- is hypersensitive to certain odours;

- ignores even pungent and unpleasant smells; has difficulty in differentiating between different odours;

- often clogs its nose, saying that "it stinks";

- does not eat food without smelling it first;

- is hypersensitive to perfume, soap, cologne;

- likes to smell various non-food items;

- likes highly seasoned foods;

- prefers foods with a mild taste; and

- has the pharyngeal reflex in the case of many odours.

A "Yes" response is worth1 point. The norm is to score 0-3 points, the risk of sensory integration disorder can be suspected if the child scores 4-10 points in this subtest. The above questions are indicative rather than purely diagnostic. Therefore, a speech therapist who suspects an SI disorder in a child should refer the child to a specialist in sensory integration for diagnosis and then therapy.

Jacek Kielin stresses the issue of stimulation of olfactory perception in the therapy of children with profound intellectual disability. The Morning Circle method, adapted by Kielin for Polish realities, uses scent therapy with the aim of [cf. Kielin, 2020, pp. 209-210]:

- activation of the sense of smell;

- collecting olfactory experiences (learning about different odours);

- search for the source of the odour; and

- association of odour with different substances.

Marta Szmaj proposes to use olfactory stimulation in the therapy of children with feeding and eating problems. Strong aromas, including cinnamon, oregano, parsley, ginger, nutmeg, allspice, cumin, curry, basil or paprika powder stimulate the sense of smell and thus encourage eating and digestion [Szmaj, 2013].

Introducing the child to different consistencies, tastes, smells and textures allows the child to experience a variety of stimulation. By providing stimuli to the different visual, tactile, olfactory and gustatory receptors, the child is exposed to sensory impressions which enhance sensory integration.

It is worth giving the child the opportunity to experience different smells. The ones in the immediate vicinity should be used. The child should get to know natural smells of flowers, herbs and food products, kitchen and bathroom smells or any other scents of nature.

Games stimulating the sense of smell be matched to the child's age and degree of sensitivity to olfactory stimuli. Examples of exercises to stimulate the sense 
of smell in children include [cf. Borkowska, Wagh, 2010; Ayres, 2015; "Integracja Sensoryczna...", 2018]:

- exploring smells in a garden, an orchard, a botanical garden, a forest, a park;

- filling different containers with spices (allspice, bay leaf, dried mint, dried sage, tea);

- making scented bags from dried lavender, mint, rosemary;

- drawing with scented pencils;

- segregating odours according to their origin;

- pairing of fragrances;

- kneading dough with scented oils or spices;

- olfactory memory.

\section{Sense of smell in gerontological speech therapy}

The sense of smell ages the fastest of all the senses because from the age of 20 onwards, people begin to undergo a physiological process which reduces the nerve fibres located in the peripheral olfactory receptors [Składzień et al., 2012, p. 162].

The aetiology of age-related olfactory impairment involves a number of factors. Anna Siudak stresses that olfactory disorders may be a consequence of diseases related to the central nervous system or may occur in patients [Siudak, 2019, pp. 202-203]:

- with cognitive impairment after neurological incidents (up to $30 \%$ of such patients);

- dementia with Lewy bodies;

- in the course of the Alzheimer's disease;

- in the course of Parkinson's disease (in 90\% of patients with this disease);

- with ENT pathologies (nasal polyposis, tumours in the nasal passages);

- with oncological lesions (in the course of radio- and chemotherapeutic treatment);

- with diabetes;

- having dentures (they can reduce the capacity of the mouth and thus accelerate the disappearance of the lingual papillae);

- using intranasal zinc gluconate containing medicines;

- with sinusitis;

- with zinc deficiency;

- with vitamin D deficiency.

As it is stressed by Sylwia Gudej, the author and co-authors indicate that, over time, it is possible to observe an increase in olfactory excitability and the progressive loss of the ability to identify and distinguish different odours [Gudej, Błaszczyk, Gromadzka-Ostrowska, 2014, p. 110]. The literature also mentions other different aspects in the case of which there is a reduction in the efficiency of the sense of smell connected with aging, namely [Czerniawska, 2012, pp. 97-98]: 
- the smell recognition threshold is increased;

- the olfactory sensitivity threshold is increased;

- the ability to assess the intensity of odours is impaired;

- the ability to verbally identify and name odours decreases;

- the ability to discriminate between odours is impaired;

- there is stronger olfactory adaptation and habituation, i.e. older people lose their sense of smell more quickly;

- cognitive memory becomes weaker;

- there is a considerable decrease in sensitivity to stimuli which activate not only the olfactory nerve but also the trigeminal nerve.

It is estimated that $75 \%$ of people over the age of 80 suffer from severe olfactory disorders and that a significant reduction in the sense of smell occurs after the seventh decade of life [Gudej, Błaszczyk, Gromadzka-Ostrowska, 2014, p. 110].

The complexity of the ageing process as well as the mechanisms responsible for disturbing the body's homeostasis, makes it impossible to identify unequivocally the factors contributing to sensory disorders, including olfactory disorders. Data in the literature indicate that the aetiology of age-related olfactory impairment is multifactorial [Gudej, Błaszczyk, Gromadzka-Ostrowska, 2014, p. 109].

Some of the causes of olfactory dysfunction in the elderly include [Gudej, Błaszczyk, Gromadzka-Ostrowska, 2014, pp. 110-112]:

- changes in both the number of olfactory receptors and innervation of the olfactory bulb;

- reduction of the olfactory surface of the mucous membrane;

- changes in the composition of the mucus in the nasal cavity, the thickness of the epithelium and the blood supply to these structures;

- general disorders of the central nervous system, including olfactory nerve pathways (or neurodegeneration);

- anatomical changes occurring in the pathways of the passage of the olfactory nerve;

- head injuries;

- laryngological and oncological diseases; and

- pharmacological treatment.

In a significant proportion of the elderly population, ageing is associated with the coexistence of various disease pathologies, including the neurodegenerative diseases mentioned above, which is one of the major factors contributing to the deterioration of the sense of smell [Gudej, Błaszczyk, Gromadzka-Ostrowska, 2014, p. 111].

Research has shown that patients with cognitive disorders, Alzheimer's disease and Parkinson's disease have a higher risk of developing dysosmia. The preclinical symptoms of Parkinson's disease include not only pain, vegetative dysfunction, sleep disorders, mental symptoms but also olfactory disorders [Gudej, Błaszczyk, Gromadzka-Ostrowska, 2014, p. 111]. 
In case of Parkinson's disease, olfactory disorders are very likely to differentiate Parkinson's disease from other extrapyramidal syndromes, being one of the first premotor symptoms of the disease [Sienkiewicz-Jarosz, 2012, p. 8]. There is also a strong link between olfactory dysfunctions and the progressive decline in episodic memory, which is one of the earliest clinical signs of Alzheimer's disease [Gudej, Błaszczyk, Gromadzka-Ostrowska, 2014, p. 111]. The findings cited by Eugenia Tęgowska and Adrianna Wosińska confirm that approximately $82 \%$ of people who were diagnosed with severe olfactory impairment at the beginning of the study and who were unaware of their problems were diagnosed with Alzheimer's disease within two years [Tęgowska, Wosińska, 2011, p. 84].

The olfactory pathways have an important place in the pathogenesis of Alzheimer's disease. This is because both the olfactory pathways and the hippocampus undergo analogous changes, where pathologies in olfactory structures result in impairment of this sense [Tęgowska, Wosińska, 2011, p. 83]. It is also vital that there is a correlation between the degree of olfactory impairment and the rate of progression of dementia and its severity [Tęgowska, Wosińska, 2011, p. 84].

Due to the dementia symptoms, it is worth mentioning here other diseases are accompanied by smell disorders, such as Creutzfeldt-Jakob disease and Pick's [cf. Czerniewska, 2012, pp. 103-104].

In the therapy of olfactory disorders in the elderly, it is possible to use the exercises and aromatic substances listed in the therapy of neurological disorders. It is also worth pointing out that the smells suitable for the therapy include the rose scent, which overcomes depressive moods, pleasant scents, such as lilies and peppermint, which increase alertness, or floral and lemon scents, which have a beneficial effect on the performance of mental tasks [Czerniawska, 2012, p. 91].

\section{Summary}

The sense of smell - so far underestimated - appears to be a very important sense for human functioning, and smell disorders are sometimes one of the diagnostic symptoms of a serious disease.

It was no coincidence that Anthony Smith wrote that "There is no other receiving device with sensitivity equal to the sense of sense, it is extremely precise, accurate and also extremely memorable" [Smith, 1983, p. 440], and Leszek Konopski and Michael Koberda referred to the sense of smell as "the unconscious king of the human senses "which" seduces us and takes us into captivity, fascinates and excites, but sometimes also puts us off" [Konopski, Koberda, 2003, p. 85].

As it can be seen from the above considerations, apart from senses such as hearing and sight, also the sense of smell should be within the scope of interest of a speech therapist. 
In relation to the sense of smell, speech therapists may:

- assess nasal patency (Czermak's test, Gutzmann's pressure test);

- assess the functioning of the sense of smell on the basis of an interview with the patient or caregiver;

- make a general evaluation of the functioning of the sense of smell, using different olfactory samples; and

- test for hypersensitivity or hyposensitivity to odours.

As part of speech therapy, speech therapists may include stimulation of the sense of smell through various exercises, e.g.:

- odour differentiation exercises;

- exercises in guessing and naming different odours;

- exercises in differentiating odour intensity;

- exercises stimulating the sense of smell with different odours;

- exercises in searching the source of smell;

- olfactory memory exercises.

Speech therapists can also use olfactory stimulation in therapeutic feeding, both with children and adults. Strong aromas such as cinnamon, oregano, parsley and others stimulate the sense of smell and thus encourage eating and digestion.

The child's feeding process is influenced, among other things, by olfactory hypersensitivity or under responsivity. Children with olfactory hypersensitivity perceive odours that are pleasant or completely imperceptible to the environment as unpleasant, or sometimes even irritating. This can be one of several causes of food aversion (along with, for example, tactile hypersensitivity in the oral cavity).

In the case of olfactory hypersensitivity, kitchen smells should be limited and the food given to the child should be odourless. It is only at the stage of olfactory stimulation that delicate and milder odours should be gradually introduced and presented several times and from an increasingly shorter distance, with the child being told about them on each occasion.

In the case of hypernasal speech, speech therapists should use exercises teaching physiological breathing, activities to differentiate inhalation and exhalation, exercises to activate the nasal resonator using nasal bone tremor sensing strategies as well as strategies to differentiate nasal and oral sounds.

Patients after laryngectomy can do exercises to improve airflow in the nasal cavity, i.e.: through making chewing movements with their mouth closed, making yawning movements with their mouth closed, breathing in the air with the wing of the nose pressed by moving the soft palate through the nose, then releasing the pressure.

The sense of smell - often underestimated until now - should become the subject of interest and more thorough studies, including speech therapy research, since it undoubtedly increases the quality of life, allows a person to explore and interpret the surrounding reality and is sometimes a symptom preceding the onset of a disease, e.g. the Alzheimer's disease. 
References

Altin F., Cingi C., Uzun T., Bal C., 2020, Olfactory and gustatory abnormalities in COVID-19 cases, "European Archives of Oto-Rhino-Laryngology", vol. 277, no. 10, pp. 2775-2781.

Ayres J., 2015, Dziecko a integracja sensoryczna, Gdańsk: Harmonia.

Belzyt J.I., 2016, Wykorzystanie wiedzy o umyśle dla funkcjonowania osób z zaburzeniami/ niepetnosprawnością zmysłu wzroku, "Niepełnosprawność. Dyskursy Pedagogiki Specjalnej", vol. 21, pp. 47-57.

Białaczewski L., 2005, Nagroda Nobla za rok 2004: odkrycie genów receptorów węchowych, "Otorynolaryngologia", vol. 4, no. 4, pp. 163-168.

Biel L., 2015, Integracja sensoryczna. Skuteczne strategie w terapii dzieci i nastolatków, Kraków: Wydawnictwo Uniwersytetu Jagiellońskiego.

Borkowska M., Wagh K., 2010, Integracja sensoryczna na co dzień, Warszawa: Państwowy Zakład Wydawnictw Lekarskich PZWL.

Boscolo-Rizzo P., Boresetto D., Spinato G., Fabbris C., Menegaldo A., Gaudioso P., Nicolai P., Tirelli G., Da Mosto M.C., Rigoli R., Polesel J., Hopkins C., 2020, New onset of loss of smell or taste in household contacts of home-isolated SARS-CoV-2-positive subjects, "European Archives of Oto-Rhino-Laryngology", vol. 277, no. 9, pp. 2637-2640.

Czerniawska E., Czy psychologia powinna mieć węch w nosie?, "Chowanna”, special volume, pp. 89-107.

Dżaman K., Pleskacz W.A., Wałkanis A., Rapiejko P., Jurkiewicz D., 2007, Ocena zmysłu smaku $i$ węchu u pacjentów z polipami nosa, "Otolaryngologia Polska", vol. LXI, no. 5, pp. 831-837.

Encyklopedia logopedii, Nosowanie zamknięte, https://www.komlogo.pl/index.php/encyklopedia /128-a/1046-nosowanie-zamkniete (accessed: 22.10.2020).

Gałkowski T., Radziszewska-Konopka M. (eds.), 2011, Wspomaganie rozwoju małego dziecka $z$ wada słuchu, Warszawa: Polski Komitet Audiofonologii.

Gudej S., Błaszczyk K., Gromadzka-Ostrowska J., 2014, Związane z wiekiem zmiany węchu i smaku, "Geriatria", no. 8, pp. 109-116.

Gunia G., 2006, Terapia logopedyczna dzieci z zaburzeniami stuchu i mowy. Wybrane problemy teorii i praktyki surdologopedycznej, Kraków: Oficyna Wydawnicza "Impuls".

Hamerlińska A., 2019a, Applying nasal airflow - inducing maneuvers with patients with hyposmia after total laryngectomy, "Współczesna Onkologia", vol. 23, no. 3, pp. 141-145.

Hamerlińska A., 2019b, Mowa przełykowa. Studium onkologopedyczne, Toruń: Wydawnictwo Adam Marszałek.

Hamerlińska A., 2019c, Węch i jego zaburzenia przedmiotem badań (również) logopedii, "Logopedia", vol. 48, no. 1, pp. 187-201.

"Integracja Sensoryczna. Kwartalnik Polskiego Stowarzyszenia Terapeutów Integracji Sensorycznej SI" 2018, vol. 3.

Izquierdo-Domínguez A., Rojas-Lechuga M.J., Chiesa-Estomba C., Calvo-Henríquez C., NinchritzBecerra E., Soriano-Reixach M., Poletti-Serafini D., Maria Villarreal I., Maza-Solano J.M., Moreno-Luna R., Villarroel P.P., Mateos-Serrano B., Agudelo D., Valcarcel F., Cuvillo A. del, Santamaría A., Mariño-Sánchez F., Aguilar J., Vergés P., Inciarte A., Soriano A., Mullol J., Alobid I., 2020a, Smell and Taste Dysfunction in COVID-19 is Associated with Younger Age in Ambulatory Settings: A Multicenter Cross-Sectional Study, "Journal Investigation Allergology and Clinical Immunology", vol. 30(5), pp. 346-357.

Izquierdo-Domínguez A., Rojas-Lechuga M.J., Mullol J., Alobid I., 2020b, Olfactory Dysfunction in the COVID-19 Outbreak, "Journal Investigation Allergology and Clinical Immunology", vol. 30(5), pp. 317-326. 
Jabłońska-Trypuć A., Farbiszewski R., 2006, Zmysł węchu u ludzi i zwierząt, "Polish Journal of Cosmetology", vol. 9, pp. 87-91.

Jadczak M., Rapiejko P., Jurkiewicz D., 2005, Metody olfaktometryczne w diagnostyce laryngologicznej, “Annales Universitatis Mariae Curie-Skłodowska. Lublin - Polonia”, vol. LX, suppl. XVI, no. 152, Section D, pp. 189-192.

Janczewski G., 2007, Węch i jego zaburzenia, [in:] G. Janczewski (ed.), Otorynolaryngologia praktyczna. Podręcznik dla studentów i lekarzy, vol. 1, Gdańsk: Via Medica, pp. 225-232.

Kielin J. (ed.), 2020, Rozwój daje radość. Terapia dzieci upośledzonych umysłowo w stopniu głębokim, Sopot: GWP.

Konopski L., Koberda M., 2003, Feromony człowieka. Środki komunikacji chemicznej między ludźmi, Warszawa: Wydawnictwo Naukowe Scholar.

Korendo M., 2017, Zmysly w komunikacji - znaczenie rozwoju percepcji wzrokowej, stuchowej oraz poznania wielozmysłowego dla prawidłowego budowania systemu językowego, [in:] J. Wojciechowska, B. Kazek (eds.), Zmysty w komunikacji. Mowa i jej uwarunkowania, Gdańsk: Harmonia, pp. 93-112.

Krzeski A., 2007, Zapalenie zatok przynosowych, [in:] G. Janczewski (ed.), Otorynolaryngologia praktyczna. Podręcznik dla studentów i lekarzy, vol. 1, Gdańsk: Via Medica, pp. 307-321.

Kucharczyk I., 2015, Funkcjonowanie emocjonalne dzieci z niepełnosprawnościa wzroku, “Niepełnosprawność. Dyskursy Pedagogiki Specjalnej”, vol. 17, pp. 91-102.

Kurkowski Z.M., 2013, Audiogenne uwarunkowania zaburzeń komunikacji językowej, Lublin: Wydawnictwo Uniwersytetu Marii Curie-Skłodowskiej.

Kurkowski Z.M., 2016, Dorobek i perspektywy polskiej surdologopedii, "Annales Universitatis Mariae Curie-Skłodowska", Sectio N, vol. 1, pp. 123-140.

Kwiatkowska A., 2014, Terapia logopedyczna osób w stanie minimalnej świadomości i zespole zamknięcia, [in:] A. Hamerlińska-Latecka, M. Karwowska (eds.), Interdyscyplinarność w logopedii, Gliwice: Komlogo Piotr Gruba, pp. 85-101.

Lechien J.R., Chiesa-Estomba C., De Siati D.R., Horoi M., Le Bon S., Rodriguez A., Dequanter D., Blecic S., El Afia F., Distinguin L., Chekkoury-Idrissi Y., Hans S., Lopez Delgado I., CalvoHenriquez Ch., Lavigne P., Falanga Ch., Barillari M.R., Cammaroto G., Khalife M., Leich P., Souchay Ch., Rossi C., Journe F., Hsieh J., Edjlali M., Carlier R., Laurence Ris L., Lovato A., De Filippis C., Coppee F., Fakhry N., Ayad T., Saussez S., 2020, Olfactory and gustatory dysfunctions as a clinical presentation of mild-to-moderate forms of the coronavirus disease (COVID-19): a multicenter European study, "European Archives of Oto-Rhino-Laryngology", vol. 277 , no. 8 , pp. 2251-2261.

Muzyka-Furtak E. (eds.), 2015, Surdologopedia. Teoria i praktyka, Gdańsk: Harmonia.

Obrębowski A., Świdziński T., Świdziński P., 2004, Wstępne badania kliniczne węchowych potencjałów wywołanych, "Otolaryngologia Polska", vol. 58, pp. 253-258.

Okła S., 2007, Chirurgiczna rehabilitacja głosu po całkowitej laryngektomii, Warszawa: Państwowy Zakład Wydawnictw Lekarskich PZWL.

Paczkowska A., Szmalec J., 2014, Nieprawidłowe przetwarzanie wzrokowe a zaburzenia integracji sensorycznej u dzieci w wieku 7-11 lat z problemami szkolnymi, "Hygeia Public Health", vol. 49(4), pp. 650-654.

Paplińska M., 2010, Konsekwencje wynikajace z braku wzroku, [in:] M. Bielska-Łach (ed.), Norweska praca socjalna, Warszawa: Wydawnictwo Akademii Pedagogiki Specjalnej, pp. 129-135.

Potargowicz E., 2008, Węch - niedoceniany zmysł człowieka, "Postępy Higieny i Medycyny Doświadczalnej", vol. 62, pp. 87-93.

Pruszewicz A., Durska-Zakrzewska A., Rydzewski B., 1984, Zachowanie się powonienia i smaku u chorych na twardziel leczonych swoiście oraz na ocenę leczonych operacyjnie, "Otolaryngologia Polska”, vol. 38(4), pp. 291-295. 
Przyrowski Z., 2002, Terapia integracji sensorycznej, [in:] M. Przybysz-Piwko (compilation), Metody wspomagające rozwój mowy w różnych jego opóźnieniach, Warszawa: DiG, pp. 204-213.

Przyrowski Z., 2012, Integracja sensoryczna: wprowadzenie do teorii, diagnozy i terapii, Warszawa: Empis.

Przyrowski Z., 2019, Integracja sensoryczna: teoria, diagnoza, terapia, Warszawa: Empis.

Rapiejko P., 2006, Zmysł węchu, "Alergoprofil”, vol. 2, no. 4(7), pp. 4-10.

Rapiejko P., 2016, Zaburzenia zmystu węchu, Warszawa: Medical Education.

Repetowski M., Kuśmierczyk K., Mazurek A., Michalska J., Olszewski J., 2010, Podstawy anatomii i fizjologii drogi węchowej oraz możliwości topodiagnostyki jej uszkodzeń z użyciem węchowych potencjałów wywołanych, "Aktualności Neurologiczne", vol. 10(2), pp. 85-88.

Resler K., 2019, Ocena wpływu zaburzeń zmystu węchu na jakość życia pacjentów z przewlekłym zapaleniem zatok przynosowych, unpublished doctoral dissertation written under the supervision of Prof. Tomasz Kręcicki at the Medical University of Wrocław.

Samoliński B., 2007, Nieżyty nosa - klasyfikacja i postępowanie, [in:] G. Janczewski (ed.), Otorynolaryngologia praktyczna. Podręcznik dla studentów i lekarzy, vol. 1, Gdańsk: Via Medica, pp. 274-288.

Sekula A., Pruszewicz A., 2019, Nosowanie, [in:] A. Pruszewicz, A. Obrębowski (eds.), Zarys foniatrii klinicznej, Poznań: Wydawnictwo Naukowe Uniwersytetu Medycznego im. Karola Marcinkowskiego w Poznaniu, pp. 232-237.

Sienkiewicz-Jarosz H., 2012, Zmyst węchu - fizjologia i patologia, "Neurologia po Dyplomie", vol. 7, no. 4 , pp. 6-10.

Siudak A., 2019, Fizjologiczne i patologiczne aspekty inwolucji zmystów - część II: dotyk, smak, powonienie, [in:] B. Kazek, J. Wojciechowska (eds.), Zmysty w procesie starzenia, Warszawa: Wydawnictwa Uniwersytetu Warszawskiego, pp. 185-208.

Skibska J., 2014, Dziecko z wada stuchu oraz Centralnymi Zaburzeniami Przetwarzania Stuchowego (CAPD). Wybrane zagadnienia, Kraków: Libron - Filip Lohner.

Składzień J., Tomik J., Gawlik J., Wiatr M., Hartwich P., 2012, Zmiany w narządach laryngologicznych $i$ ich schorzenia wynikające ze starzenia się organizmu, [in:] A. Marchewka, Z. Dąbrowski, J.A. Żołądź (eds.), Fizjologia starzenia się. Profilaktyka i rehabilitacja, Warszawa: Wydawnictwo Naukowe PWN, pp. 157-165.

Smith A., 1983, Ciało, trans. H. Wasylkiewicz, Warszawa: Państwowy Zakład Wydawnictw Lekarskich PZWL.

Styczek I., 1979, Logopedia, Warszawa: Państwowe Wydawnictwo Naukowe.

Szmaj M., 2013, Ustna sprawność ruchowa w karmieniu i żywieniu dziecka, training materials, Kutno.

Tęgowska E., Wosińska A., 2011, Rola nauk biologicznych w rozumieniu genezy i nowego podejścia terapeutycznego do choroby Alzheimera, "Postępy Higieny i Medycyny Doświadczalnej", vol. 65, pp. 73-92.

Tomaszewska M., Krzeski A., 2018, Przewlekłe zapalenie zatok przynosowych - klasyfikacja, etiopatogeneza i leczenie, "Magazyn Otorynolaryngologiczny", vol. XVII (3), no. 67, pp. 75-91.

Wróblewska A., 2019, Język osób z niepetnosprawnością wzroku: leksyka i metaforyka środowiskowa, "Poradnik Językowy", vol. 3, pp. 81-92.

Zimmer-Nowicka J., Błaszczyk T., Kaczmarczyk D., Morawiec-Sztandera A., 2008, Wpływ ćwiczeń wymuszających przeplyw powietrza przez jamę nosową na funkcję zmystu węchu u chorych po całkowitym usunięciu krtani, “Otorynolaryngologia”, vol. 7, no. 3, pp. 133-138. 


\begin{tabular}{|l|l|} 
CC & $\begin{array}{l}\text { C by the author, licensee Łódź University - Łódź University Press, Łódź, Poland. } \\
\text { This article is an open access article distributed under the terms and conditions } \\
\text { of the Creative Commons Attribution license CC-BY-NC-ND } 4.0 \\
\text { (https://creativecommons.org/licenses/by-nc-nd/4.0/) }\end{array}$ \\
\cline { 2 - 2 } & Received: 19.11.2020. Accepted: 10.09.2021. \\
\hline
\end{tabular}

